\title{
FAKTOR-FAKTOR YANG MEMPENGARUHI HARGA SAHAM DAN DAMPAKNYA PADA NILAI PERUSAHAAN \\ (Studi Kasus pada Perusahaan Sub Sektor Pertambangan Minyak dan Gas Bumi yang Terdaftar di Bursa Efek Indonesia Tahun 2013-2017)
}

\author{
Nardi Sunardi ${ }^{1)}$ R. Dewangga Indra Permana ${ }^{2)}$ \\ 1) dosen universitas pamulang, email : dosen01030@unpam.ac.id \\ ${ }^{2)}$ mahasiwa universitas pamulang.
}

ARTICLES

INFORMATION

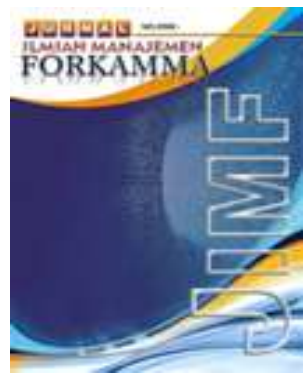

\section{JURNAL ILMIAH MANAJEMEN FORKAMMA}

\author{
Vol.2, No.2, Maret 2019 \\ Halaman : $62-72$ \\ (c) LPPM \& FORKAMMA
}

Prodi Magister Manajemen UNVERSITAS PAMULANG

$$
\begin{array}{cc}
\text { ISSN (online) } & : 2599-171 X \\
\text { ISSN (print) } & : 2598-9545
\end{array}
$$

Keyword:

$R O A, I N F, S P, Q$

JEL. classification :

O15,

\section{Contact Author : \\ PRODI \\ MAGISTER MANAJEMEN \& FORKAMMA UNPAM \\ JL.Surya Kencana No.1 Pamulang \\ Tangerang Selatan - Banten \\ Telp. (021) 7412566, Fax (021) 7412491 Email : \\ jurnalforkamma.unpam@gmail.com}

Penelitian ini bertujuan untuk menguji dan mengetahui pengaruh baik secara parsial ataupun secara simultan antara $R O A$, INF, dan SP terhadap nilai perusahaan (Q) pada perusahaan - perusahaan sub sektor pertambangan minyak dan gas bumi yang terdaftar di Bursa Efek Indonesia periode tahun 2013 sampai dengan periode tahun 2017.

Sampel dalam penelitian ini adalah 8 perusahaan yang dipilih menggunakan teknik sampling jenuh dengan analisis regresi dilakukan didasarkan pada hasil analisis data panel.

Penelitian ini menyimpulkan beberapa hal sebagai berikut: Secara Simultan, Return on Asset (ROA), Inflasi (INF) dan Stock Price (SP) dengan f-Statistic 1,871768 < f-tabel 2,87 berpengaruh positif tidak signifikan terhadap Nilai Perusahaan (Q). Sedangkan nilai Adjusted R-square 0,062845 dimana $Q$ dipengaruhi oleh ROA, INF, dan SP sebesar $6,28 \%$ dan sisanya sebanyak $93,71 \%$ dipengaruhi oleh faktor lain diluar penelitian ini. Artinya, secara bersama-sama, Return on Asset (ROA), Inflasi (INF) dan Stock Price (SP) memiliki pengaruh yang positif tetapi tidak signifikan terhadap Nilai Perusahaan (Q) sebesar 6,28\%.

This study aims to examine and determine the effect of either partially or simultaneously between ROA, INF, and SP on firm value $(Q)$ in companies of the oil and gas mining sub-sector listed on the Indonesia Stock Exchange from the period of 2013 to the period in 2017.

The sample in this study were 8 companies selected using saturated sampling techniques with regression analysis performed based on the results of panel data analysis.

This study concludes several things as follows: Simultaneously, Return on Assets (ROA), Inflation (INF) and Stock Price $(S P)$ with $f$-Statistic $1.871768<$-table 2.87 has no significant positive effect on Firm Value (Q). While the Adjusted $R$-square value is 0.062845 where $Q$ is influenced by $R O A$, INF, and SP of $6.28 \%$ and the remaining $93.71 \%$ is influenced by other factors outside of this study. This means that together, Return on Assets (ROA), Inflation (INF) and Stock Price (SP) have a positive but not significant effect on Corporate Value (Q) of $6.28 \%$. 


\section{A. Pendahuluan}

Perkembangan perekonomian yang semakin pesat pada masa sekarang ini, menyebabkan orang dapat melakukan transaksi ekonomi dengan mudah melalui berbagai cara. Salah satunya yaitu kegiatan investasi yang dilakukan melalui pasar modal. Pasar modal mempertemukan antara pihak yang memiliki kelebihan dana dan pihak yang membutuhkan dana melalui instrumen jangka panjang seperti saham. Saham merupakan surat berharga yang diperdagangkan di pasar modal sebagai tanda bukti kepemilikan atas suatu perusahaan. Pemegang saham yang terdapat dalam suatu perusahaan turut memiliki sebagian dari perusahaan tersebut.

"Saham merupakan salah satu instrumen pasar modal yang paling menarik minat investor karena dapat memberikan tingkat keuntungan yang menarik. Harga saham adalah salah satu hal yang dijadikan indikator pengelolaan perusahaan yang menunjukkan nilai dari suat prestasi perusahaan. Keberhasilan dalam menghasilkan keuntungan akan memberikan kepuasan bagi para investor. Semakin naik nilai harga saham, maka semakin banyak pula saham perusahaan yang diminati oleh investor, dan dengan demikian perusahaan akan memperoleh capital gain dan citra yang lebih baik sehingga memudahkan bagi pihak manajemen untuk memperoleh dana. Saham (Stock) merupakan tanda penyertaan atau pemilikan seseorang atau badan dalam suatu perusahaan atau perseroan terbatas yang berwujud selembar kertas yang menerangkan bahwa pemilik saham tersebut adalah pemilik perusahaan yang menerbitkan surat berharga tersebut" (Darmadji dan Fakhruddin; 2012). Menurut Agus Sartono (2008) menyatakan bahwa "harga pasar saham terbentuk melalui mekanisme permintaan dan penawaran yang terjadi di pasar modal". Sedangkan menurut Brigham dan Houston (2010), "harga saham menentukan kekayaan pemegang saham. Maksimalisasi kekayaan pemegang saham diterjemahkan menjadi maksimalisasi harga saham perusahaan. Harga saham pada satu waktu tertentu akan bergantung pada arus kas yang diharapkan diterima di masa yang akan datang. Inflasi adalah faktor makro ekonomi yang dapat menguntungkan sekaligus merugikan suatu perusahaan. Pada dasarnya inflasi yang tinggi tidak disukai oleh pelaku pasar modal karena akan meningkatkan biaya produksi dan biaya operasional perusahaan". Tetapi, disisi lain inflasi juga akan meningkatkan harga jual produk perusahaan tersebut. Permana dan Sularto (2008) menyatakan "bahwa salah satu faktor yang dapat mempengaruhi ekspektaksi harga saham tingkat inflasi".

"Analisis rasio keuangan memudahkan penggunanya mengetahui hal - hal atau bidang apa saja dalam perusahaan yang sedang mengalami masalah dan juga mampu membantu mengetahui kinerja perusahaan secara keseluruhan" (Cincin Haosana, 2012). Menurut Kieso et al (2002: 223), "terdapat beberapa rasio untuk mengukur profitabilitas. Salah satunya adalah Return on Asset (ROA). ROA menurut Kieso et al (2002: 223) merupakan rasio yang digunakan untuk mengukur profitabilitas aktiva secara keseluruhan. Oleh sebab itu, semakin positif nilai ROA (semakin besar), maka semakin baik pula kemampuan perusahaan dalam mendayagunakan aktiva yang dimilikinya untuk menghasilkan laba. Sebaliknya, ROA yang negatif (semakin kecil) menunjukkan bahwa dari total aktiva yang digunakan, perusahaan tidak mampu memberikan laba. $Q$ Ratio merupakan suatu rasio yang menawarkan penjelasan nilai dari suatu perusahaan di pasar dimana nilai pasar suatu perusahaan seharusnya sama dengan biaya ganti aktivanya. Jika nilai $Q$ Ratio perusahaan lebih dari satu, berarti nilai pasar perusahaan tersebut lebih besar daripada aktiva perusahaan yang tercatat. Oleh karena itu, pasar akan menilai baik perusahaan yang memiliki nilai $Q$ Ratio yang tinggi. Sebaliknya, jika nilai $Q$ Ratio kurang dari satu mengindikasikan bahwa biaya ganti aktiva lebih besar daripada nilai pasar perusahaan sehingga pasar akan menilai kurang perusahaan tersebut. Para investor dapat memanfaatkan rasio-rasio yang ada pada model $Q$ Ratio dan laporan keuangan 
sebagai pertimbangan dalam memilih saham yang akan diinvestasikan dan melihat pengaruhnya terhadap return yang akan mereka terima".

Hal inilah yang menjadi dasar dalam penelitian ini yang diberi judul "FAKTOR FAKTOR YANG MEMPENGARUHI HARGA SAHAM DAN DAMPAKNYA PADA NILAI PERUSAHAAN" Studi Kasus Pada Perusahaan Sub Sektor Pertambangan Minyak Dan Gas Bumi Yang Terdaftar Di Bursa Efek Jakarta.

\section{B. Perumusan Masalah}

Berdasarkan latar belakang, identifikasi masalah, dan pembatasan masalah, maka perumusan masalah dalam penelitian ini adalah:

1. Bagaimana pengaruh Return on Asset (ROA) terhadap harga saham yang diproksikan dengan stock price pada perusahaan Sub Sektor Pertambangan Minyak dan Gas Bumi yang terdaftar di Bursa Efek Indonesia periode tahun 2013 - 2017?

2. Bagaimana pengaruh inflasi terhadap terhadap harga saham yang diproksikan dengan sock price pada perusahaan Sub Sektor Pertambangan Minyak dan Gas Bumi yang terdaftar di Bursa Efek Indonesia periode tahun 2013 - 2017?

3. Bagaimana pengaruh Return on Asset (ROA) dan inflasi secara bersama - sama terhadap harga saham yang diproksikan dengan stock price pada perusahaan Sub Sektor Pertambangan Minyak dan Gas Bumi yang terdaftar di Bursa Efek Indonesia periode tahun $2013-2017 ?$

4. Bagaimana pengaruh Return on Asset (ROA) terhadap nilai perusahaan yang diproksikan dengan $Q$ Ratio pada perusahaan Sub Sektor Pertambangan Minyak dan Gas Bumi yang terdaftar di Bursa Efek Indonesia periode tahun 2013 - 2017?

5. Bagaimana pengaruh Inflasi terhadap nilai perusahaan yang diproksikan dengan $Q$ Ratio pada perusahaan Sub Sektor Pertambangan Minyak dan Gas Bumi yang terdaftar di Bursa Efek Indonesia periode tahun 2013 - 2017?

6. Bagaimana pengaruh harga saham yang diproksikan dengan stock price terhadap nilai perusahaan yang diproksikan dengan $Q$ Ratio pada perusahaan Sub Sektor Pertambangan Minyak dan Gas Bumi yang terdaftar di Bursa Efek Indonesia periode tahun $2013-2017 ?$

7. Bagaimana pengaruh Return on Asset (ROA), Inflasi, dan harga saham (stock price) secara bersama-sama terhadap nilai perusahaan pada perusahaan Sub Sektor Pertambangan Minyak dan Gas Bumi yang terdaftar di Bursa Efek Indonesia periode tahun 2013-2017?

\section{Tujuan Penelitian}

1. Untuk mengetahui pengaruh Return on Asset (ROA) terhadap harga saham yang diproksikan dengan stock price pada perusahaan Sub Sektor Pertambangan Minyak dan Gas Bumi yang terdaftar di Bursa Efek Indonesia periode tahun 2013 $-2017$.

2. Untuk mengetahui pengaruh inflasi terhadap terhadap harga saham yang diproksikan dengan sock price pada perusahaan Sub Sektor Pertambangan Minyak dan Gas Bumi yang terdaftar di Bursa Efek Indonesia periode tahun 2013 $-2017$.

3. Untuk mengetahui pengaruh Return on Asset (ROA) dan inflasi secara bersama sama terhadap harga saham yang diproksikan dengan stock price pada perusahaan Sub Sektor Pertambangan Minyak dan Gas Bumi yang terdaftar di Bursa Efek Indonesia periode tahun 2013 - 2017.

4. Untuk mengetahui pengaruh Return on Asset (ROA) terhadap nilai perusahaan yang diproksikan dengan $Q$ Ratio pada perusahaan Sub Sektor Pertambangan Minyak dan Gas Bumi yang terdaftar di Bursa Efek Indonesia periode tahun 2013 $-2017$. 
5. Untuk mengetahui pengaruh Inflasi terhadap nilai perusahaan yang diproksikan dengan $Q$ Ratio pada perusahaan Sub Sektor Pertambangan Minyak dan Gas Bumi yang terdaftar di Bursa Efek Indonesia periode tahun 2013 - 2017.

6. Untuk mengetahui pengaruh harga saham yang diproksikan dengan stock price terhadap nilai perusahaan yang diproksikan dengan $Q$ Ratio pada perusahaan Sub Sektor Pertambangan Minyak dan Gas Bumi yang terdaftar di Bursa Efek Indonesia periode tahun 2013 - 2017.

7. Untuk mengetahui pengaruh Return on Asset (ROA), Inflasi, dan harga saham (stock price) secara bersama-sama terhadap nilai perusahaan pada perusahaan Sub Sektor Pertambangan Minyak dan Gas Bumi yang terdaftar di Bursa Efek Indonesia periode tahun 2013 - 2017.

\section{Landasan Teori}

Kinerja perusahaan yang di proksikan dengan Return on Asset (ROA) menggambarkan kinerja perusahaan bedasarkan kemampuan perusahaan dalam mendayagunakan jumlah asset yang dimiliki. ROA yang semakin bertambah menggambarkan kinerja perusahaan yang semakin baik (Dianata Eka dalam Aryanti dan Mawardi: 2016). "ROA menggambarkan kemampuan aset - aset yang dimiliki perusahaan dalam menghasilkan laba, setelah disesuaikan dengan biaya - biaya untuk mendanai aset tersebut. ROA yang positif (semakin besar) menunjukkan bahwa dari total aktiva yang dipergunakan untuk beroperasi, perusahaan mampu memberikan laba bagi perusahaan. Sebaliknya, ROA yang negative (semakin kecil) menunjukkan bahwa dari total aktiva yang digunakan belum mampu memberikan laba sehingga mendapat kerugian".

Menurut Tandelilin dalam Bambang Sudarsono (2016), "inflasi merupakan kecenderungan terjadinya peningkatan harga produk secara keseluruhan sehingga apabila tingkat inflasi tinggi, akan mengurangi tingkat pendapatan riil yang diperoleh investor dari investasi, dan sebaliknya apabila tingkat inflasi suatu negara mengalami penurunan maka tingkat resiko daya beli uang dan resiko pendatap riil akan menurun. Inflasi merupakan suatu kejadian yang menggambarkan situasi dan kondisi dimana harga barang mengalami kenaikan dan nilai mata uang mengalami pelemahan, dan jika ini terjadi terus menerus maka akan mengakibatkan pada memburuknya kondisi ekonomi secara menyeluruh serta mampu mengguncang tatanan stabilitas politik suatu negara" (Fahmi: 2013).

Menurut Zuliarni (2012), "harga saham adalah salah satu indikator keberhasilan pengelolaan perusahaan. Apabila harga saham suatu perusahaan terus mengalami kenaikan, maka investor atau calon investor akan menilai bahwa perusahaan tersebut berhasil dalam mengelola usahanya. Darmadji dan Fakhruddin (2012) menyatakan bahwa harga saham dapat berubah naik ataupun turun dalam hitungan waktu yang sangat cepat tergantung dengan banyaknya permintaan dan penawaran antara pembeli dan penjual saham".

"Nilai perusahaan menggambarkan seberapa baik atau buruk manajemen mengelola kekayaannya, hal ini bisa dilihat dari pengukuran kinerja keuangan yang diperoleh". Suatu perusahaan akan berusaha untuk memaksimalkan nilai perusahaannya. Menurut Brigham dan Houston (2010), "Tujuan utama perusahaan adalah memaksimumkan nilai perusahaan sebagai pengukur keberhasilan perusahaan karena dengan meningkatnya nilai perusahaan berarti tingkat kemakmuran pemilik perusahaan atau para pemegang saham juga meningkat. Pengukuran nilai perusahaan sering kali dilakukan dengan menggunakan rasio-rasio penilaian atau rasio pasar. Rasio penilaian merupakan ukuran kinerja yang paling menyeluruh untuk suatu perusahaan karena mencerminkan pengaruh gabungan dari rasio hasil pengembalian risiko. Salah satu alternatif yang digunakan dalam menilai nilai perusahaan adalah dengan menggunakan Tobin's Q". 


\section{E. Metodologi}

ISSN (print) : 2598-9545 \& ISSN (online) : 2599-171X

Jenis Penelitian ini "menggunakan pendekatan kuantitatif yang merupakan masing-masing variabel maupun antar variabel didasari pada skala pengukuran kuantitatif. Populasi dalam penelitian ini adalah perusahaan Sub Sektor Pertambangan Minyak dan Gas Bumi yang terdaftar di Bursa Efek Indonesia periode tahun 2013 - 2017 yang termuat dalam www.idx.co.id". Penarikan sampel yang dilakukan adalah dengan menggunakan metode sampling jenuh, dimana semua anggota populasi digunakan menjadi sampel.

Sampel Penelitian

\begin{tabular}{|c|l|l|}
\hline No & Kode Perusahaan & Nama Perusahaan \\
\hline \hline 1 & APEX & PT. Apexindo Pratama Duta Tbk \\
\hline 2 & ARTI & PT. Ratu Prabu Energi Tbk \\
\hline 3 & BIPI & PT. Benakat Integra Tbk \\
\hline 4 & ELSA & PT. Elnusa Tbk \\
\hline 5 & ENRG & PT. Energi Mega Persada Tbk \\
\hline 6 & ESSA & PT. Surya Esa Perkasa Tbk \\
\hline 7 & MEDC & PT. Medco Energi International Tbk \\
\hline 8 & RUIS & PT. Radiant Utama Interinsco Tbk \\
\hline
\end{tabular}

"Metode analisis data yang dilakukan dalam penelitian ini menggunakan metode analisis regresi data panel, yaitu data yang diperoleh dari hasil cross section yang diamati secara berulang pada unit individu yang sama pada krun waktu yang berbeda. Dengan kata lain, data panel merupakan penggabungan data dari deret waktu (time series) dengan populasi penelitian (cross section)" (Juanda dan Junaidi (2012) dalam Ahmad Dzunurain (2014)).

"Pengolahan data dilakukan menggunakan bantuan aplikasi perangkat lunak (software) statistik yaitu Microsoft Office Excel 2016 dalam pembuatan tabel dan grafik untuk analisi deskriptif dan perangkat lunak (software) pengolah data EViews Versi 9.0 untuk membatu dalam menganalisis data dalam pengujian signifikasi analisi regresi linier berganda data panel".

\section{F. Hasil dan Pembahasan}

Penelitian ini melakukan estimasi faktor-faktor yang mempengaruhi harga saham dan pengaruhnya terhadap nilai perusahaan

\section{Analisis Deskripsi Data Statistik}

Sample: 140

\section{Analisis Deskripsi Data Statistik}

\begin{tabular}{lccrc}
\hline \hline & $\mathrm{Q}$ & $\mathrm{SP}$ & \multicolumn{1}{c}{ ROA } & INF \\
\hline \hline Mean & 0.378031 & 582.4308 & 1.483379 & 5.344150 \\
Median & 0.400677 & 230.0000 & 2.476356 & 3.610150 \\
Maximum & 0.519546 & 3325.000 & 10.63011 & 8.380200 \\
Minimum & 0.193169 & 50.00000 & -18.86836 & 3.020100 \\
Std. Dev. & 0.091971 & 820.1827 & 6.430326 & 2.509360 \\
Skewness & -0.396479 & 2.287803 & -1.619046 & 0.390791 \\
Kurtosis & 2.085401 & 7.314935 & 5.934309 & 1.176453
\end{tabular}




$\begin{array}{lcccc}\text { Jarque-Bera } & 2.442124 & 65.92474 & 31.82568 & 6.560322 \\ \text { Probability } & 0.294917 & 0.000000 & 0.000000 & 0.037622 \\ \text { Sum } & 15.12122 & 23297.23 & 59.33517 & 213.7660 \\ \text { Sum Sq. Dev. } & 0.329891 & 26235284 & 1612.615 & 245.5786 \\ \text { Observations } & 40 & 40 & 40 & 40\end{array}$

Sumber : Hasil output data panel Eviews 9.0

\section{Kesimpulan Model}

Berdasarkan hasil pengujian pemilihan model data panel, maka diperoleh kesimpulan sebagai berikut:

\section{Kesimpulan Pengujian Model Regresi Data Panel}

\begin{tabular}{|c|c|c|c|}
\hline No & Metode & Pengujian & Hasil \\
\hline 1. & Chow-Test & OLS Vs. FEM & FEM \\
\hline 2. & Hausman Test & FEM Vs. REM & REM \\
\hline 3. & Lagrange Multiplier & OLS Vs. REM & REM \\
\hline
\end{tabular}

\section{Uji Hipotesis}

Hipotesis 1

\section{Estimasi Regresi Data Panel ROA terhadap SP}

Dependent Variable: SP

Method: Panel EGLS (Cross-section random effects)

Date: 01/16/19 Time: 14:12

Sample: 20132017

Periods included: 5

Cross-sections included: 8

Total panel (balanced) observations: 40

Swamy and Arora estimator of component variances

\begin{tabular}{ccccc}
\hline \hline Variable & Coefficient & Std. Error & t-Statistic & Prob. \\
\hline \hline ROA & 8.081298 & 9.582348 & 0.843353 & 0.4043 \\
C & 570.4431 & 266.6544 & 2.139261 & 0.0389 \\
\hline
\end{tabular}

Hipotesis 2

Sumber : Hasil output data panel Eviews 9.0

\section{Estimasi Regresi Data Panel INF terhadap SP}

Dependent Variable: SP

Method: Panel EGLS (Cross-section random effects)

Date: 01/16/19 Time: 14:13

Sample: 20132017 
ISSN (print) : 2598-9545 \& ISSN (online) : 2599-171X

Periods included: 5

Cross-sections included: 8

Total panel (balanced) observations: 40

Swamy and Arora estimator of component variances

\begin{tabular}{crrrr}
\hline \hline Variable & Coefficient & Std. Error & t-Statistic & Prob. \\
\hline \hline INF & 29.43522 & 20.09313 & 1.464940 & 0.1512 \\
C & 425.1245 & 305.7628 & 1.390374 & 0.1725 \\
\hline \hline
\end{tabular}

Hipotesis 3

Sumber : Hasil output data panel Eviews 9.0

\section{Estimasi Regresi Data Panel ROA dan INF terhadap SP}

Dependent Variable: SP

Method: Panel EGLS (Cross-section random effects)

Date: 01/16/19 Time: 14:15

Sample: 20132017

Periods included: 5

Cross-sections included: 8

Total panel (balanced) observations: 40

Swamy and Arora estimator of component variances

\begin{tabular}{ccccc}
\hline \hline Variable & Coefficient & Std. Error & t-Statistic & Prob. \\
\hline \hline ROA & 4.670564 & 9.892716 & 0.472122 & 0.6396 \\
INF & 26.70311 & 21.08342 & 1.266546 & 0.2132 \\
C & 432.7971 & 287.9329 & 1.503118 & 0.1413 \\
\hline
\end{tabular}

Effects Specification

\begin{tabular}{|c|c|c|c|}
\hline & \multicolumn{2}{|l|}{ (1) } & Rho \\
\hline $\begin{array}{l}\text { Cross-section random } \\
\text { Idiosyncratic random }\end{array}$ & & $\begin{array}{l}739.6162 \\
317.7079\end{array}$ & $\begin{array}{l}0.8442 \\
0.1558\end{array}$ \\
\hline \multicolumn{4}{|c|}{ Weighted Statistics } \\
\hline R-squared & 0.057341 & Mean dependent var & 109.8782 \\
\hline Adjusted R-squared & 0.006386 & S.D. dependent var & 324.3589 \\
\hline S.E. of regression & 323.3216 & Sum squared resid & 3867864. \\
\hline F-statistic & 1.125327 & Durbin-Watson stat & 1.403382 \\
\hline Prob(F-statistic) & 0.335401 & & \\
\hline
\end{tabular}

Sumber : Hasil output data panel Eviews 9.0

Hipotesis 4

\section{Estimasi Regresi Data Panel ROA terhadap Q}

Dependent Variable: Q

Method: Panel EGLS (Cross-section random effects)

Date: 01/16/19 Time: 14:19

Sample: 20132017

Periods included: 5

Cross-sections included: 8

Total panel (balanced) observations: 40 
ISSN (print) : 2598-9545 \& ISSN (online) : 2599-171X

Swamy and Arora estimator of component variances

\begin{tabular}{crrrr}
\hline \hline Variable & Coefficient & Std. Error & t-Statistic & Prob. \\
\hline \hline ROA & -0.002709 & 0.001442 & -1.878932 & 0.0679 \\
C & 0.382049 & 0.022135 & 17.26001 & 0.0000 \\
\hline
\end{tabular}

Hipotesis 5

Sumber : Hasil output data panel Eviews 9.0

\section{Estimasi Regresi Data Panel INF terhadap Q}

Dependent Variable: $Q$

Method: Panel EGLS (Cross-section random effects)

Date: 01/16/19 Time: 14:20

Sample: 20132017

Periods included: 5

Cross-sections included: 8

Total panel (balanced) observations: 40

Swamy and Arora estimator of component variances

\begin{tabular}{crrrr}
\hline \hline Variable & Coefficient & Std. Error & t-Statistic & Prob. \\
\hline \hline INF & -0.004090 & 0.003134 & -1.304931 & 0.1998 \\
C & 0.399887 & 0.034307 & 11.65616 & 0.0000 \\
\hline \hline
\end{tabular}

Hipotesis 6

Sumber : Hasil output data panel Eviews 9.0

\section{Estimasi Regresi Data Panel SP terhadap Q}

Dependent Variable: $Q$

Method: Panel EGLS (Cross-section random effects)

Date: 01/16/19 Time: 14:21

Sample: 20132017

Periods included: 5

Cross-sections included: 8

Total panel (balanced) observations: 40

Swamy and Arora estimator of component variances

\begin{tabular}{crrrr}
\hline \hline Variable & Coefficient & Std. Error & t-Statistic & Prob. \\
\hline \hline SP & $1.65 E-05$ & $2.14 \mathrm{E}-05$ & 0.771045 & 0.4454 \\
C & 0.368439 & 0.028317 & 13.01127 & 0.0000
\end{tabular}

Hipotesis 7

Sumber : Hasil output data panel Eviews 9.0

\section{Estimasi Regresi Data Panel ROA, INF, dan SP terhadap Q}

Dependent Variable: Q

Method: Panel EGLS (Cross-section random effects)

Date: 01/16/19 Time: 14:22

Sample: 20132017

Periods included: 5

Cross-sections included: 8 
Total panel (balanced) observations: 40

Swamy and Arora estimator of component variances

\begin{tabular}{|c|c|c|c|c|}
\hline Variable & Coefficient & Std. Error & t-Statistic & Prob. \\
\hline SP & 2.77E-05 & 2.03E-05 & 1.365250 & 0.1806 \\
\hline ROA & -0.002401 & 0.001521 & -1.579130 & 0.1231 \\
\hline INF & -0.003501 & 0.003365 & -1.040443 & 0.3051 \\
\hline C & 0.384154 & 0.029183 & 13.16341 & 0.0000 \\
\hline \multicolumn{5}{|c|}{ Effects Specification } \\
\hline & & & S.D. & Rho \\
\hline Cross-section random & & & 0.057841 & 0.5726 \\
\hline Idiosyncratic random & & & 0.049976 & 0.4274 \\
\hline \multicolumn{5}{|c|}{ Weighted Statistics } \\
\hline R-squared & 0.134934 & \multirow{5}{*}{\multicolumn{2}{|c|}{$\begin{array}{l}\text { Mean dependent var } \\
\text { S.D. dependent var } \\
\text { Sum squared resid } \\
\text { Durbin-Watson stat }\end{array}$}} & 0.136253 \\
\hline Adjusted R-squared & 0.062845 & & & 0.053468 \\
\hline S.E. of regression & 0.051760 & & & 0.096449 \\
\hline F-statistic & 1.871768 & & & 0.755814 \\
\hline Prob(F-statistic) & 0.151822 & & & \\
\hline
\end{tabular}

\section{G. Kesimpulan}

Sumber : Hasil output data panel Eviews 9.0

1. Secara parsial, Return on Asset (ROA) berpengaruh positif tidak signifikan terhadap Stock Price (SP)

2. Secara parsial, Inflasi (INF) berpegaruh positif tidak signifikan terhadap Stock Price (SP).

3. Secara Simultan Return on Asset (ROA) dan Inflasi (INF) berpengaruh positif tidak signifikan terhadap Stock Price (SP) dengan dengan $f$-Statistic $1,125327<\mathrm{f}$-tabel 2,87 dan nilai Adjusted $R$-square $=0,006386$ Positive $(+)$ dengan nilai Prob (FStatistic) $=0,335401>0,05$ maka dikatakan tidak signifikan. Artinya, secara bersama-sama, Return on Asset (ROA) dan Inflasi (INF) memiliki pengaruh yang positif tetapi tidak signifikan terhadap harga saham (Stock Price) sebesar 0,64\%.

4. Secara parsial, Return on Asset (ROA) berpengaruh negatif tidak signifikan terhadap Nilai Perusahaan (Q).

5. Secara Parsial, Inflasi (INF) berpengaruh negatif tidak signifikan terhadap Nilai Perusahaan (Q).

6. Secara parsial, Stock Price (SP) berpengaruh positif tidak signifikan terhadap Nilai Perusahaan (Q).

7. Secara Simultan, Return on Asset (ROA), Inflasi (INF) dan Stock Price (SP) dengan $f$-Statistic $1,871768<$ f-tabel 2,87 berpengaruh positif tidak signifikan terhadap Nilai Perusahaan (Q). Sedangkan nilai Adjusted R-square 0,062845 dimana $Q$ dipengaruhi oleh ROA, INF, dan SP sebesar $6,28 \%$ dan sisanya sebanyak $93,71 \%$ dipengaruhi oleh faktor lain diluar penelitian ini.. Artinya, secara bersama-sama, Return on Asset (ROA), Inflasi (INF) dan Stock Price (SP) memiliki pengaruh yang positif tetapi tidak signifikan terhadap Nilai Perusahaan (Q) sebesar $6,28 \%$. 


\section{H. Daftar Pustaka}

Abiddin, Zaenal. 2017. Determinan Return Saham Dan Implikasinya Terhadap Nilai Perusahaan Property and Real Estate Go Public di Indonesia. Open Journal. Universitas Pamulang

Agus, Sartono. 2010, Manajemen Keuangan Teori dan Aplikasi, Yogyakarta: Penerbit BPFE.

Arif, Sugiono dan Edy, Untung. 2018. Panduan Praktis dan Dasar Analisis Laporan Keuangan. Grasindo, Jakarta.

Bangun, Nurainun, dan Sinta Wati. 2007. Analisis Pengaruh Profitabilitas Dan Kebijakan Dividen Terhadap Nilai Perusahaan Perdagangan, Jasa, Dan Investasi Yang Terdaftar Di Bursa Efek Jakarta: Jurnal Akuntansi. Tahun IX, No.2, Mei 2007: 107120.

Brigham, E.F., dan J. Houston. 2001. Manajemen Keuangan. Edisi Kedelapan. Edisi Indonesia. Penerjemah Hermawan Wibowo. Buku II. Jakarta: Erlangga.

Brigham, Eugene F. dan Joel F. Houston. 2009. Dasar-dasar Manajemen Keuangan. Buku Satu, Edisi kesepuluh, Alih bahasa Ali Akbar Yulianto. Jakarta: Salemba Empat.

Brigham, Eugene F., and Houston Joel F, 1998, Fundamentals of Financial Management, Eight Edition, The Dryden Press, Orlando.

Brigham, F.E. and Houston, F.J. (2010), Dasar-dasar Manajemen Keuangan, Jakarta: Penerbit Salemba Empat.

Darmadji \& Fakhruddin, 2011, Pasar Modal di Indonesia, edisi 3, Salemba Empat, Jakarta.

Darmadji, T. Dan Fakhrudin, H. 2012, Pasar Modal di Indonesia, Jakarta:Penerbit Alfabeta.

Dewi, Gusti Ayu Ketut Chandni. Sudiartha, Gede Merta. 2014. Pengaruh Price Earnings Ratio, Dividend Payout Ratio, Ireturn On Assets, Tingkat Suku Bunga SBI, Serta Kurs Dollar AS terhadap Harga Saham. E-Jurnal Manajemen Universitas Udayana

Ema, Novasari. 2013, Pengaruh PER, EPS, ROA DAN DER Terhadap harga Saham

Fahmi, Irham, dan Hadi. 2011. Teori Portofolio dan Analisis Investasi. Edisi Kedua. Bandung: Alfabeta

Fahmi, Irham. 2014, Manajemen Keuangan Perusahaan dan Pasar Modal, Jakarta: Penerbit Mitra Wcana Media.

Fahmi, Irham. 2012. Analisis Laporan Keuangan. Cetakan Ke-2. Bandung: Alfabeta.

Fahmi, Rijal. 2006. Analisis Pengaruh Kinerja Keuangan Terhadap Volume Perdagangan Saham Perusahaan Perbankan. Skripsi S1, Fakultas Ekonomi Universitas Muhammadiyah Malang.

Ginting, Maria Ratna Marisa. 2016. Pengaruh Tingkat Suku Bunga, Nilai Tukar Dan Inflasi Terhadap Harga Saham (Studi Pada Sub-Sektor Perbankan Di Bursa Efek Indonesia Periode 2011-2015). Journal Vol. 35, no.2. Universitas Brawijaya

Ghozali, I. 2011, Aplikasi Analisis Multivariate Dengan Program IBM SPSS,

Ghozali, I. 2012. Aplikasi Analisis Multivariate dengan Program IBM SPSS 20. Semarang: Cetakan Keenam. Badan Penerbit Universitas Diponegoro.

Ghozali, Imam. 2006. Aplikasi Analisis Multivariate Dengan Program SPSS. Cetakan Keempat. Semarang: Badan Penerbit Universitas Diponegoro. Semarang: Penerbit UNDIP.

Gujarati, Damodar, N, 2003, Basic Econometrics, "Fourth Edition,International Edition, Mcgraw-Hill.

Hadi, Nor. 2013, Corporate Socisl Responsinility, Yogyakarta: Penerbit Graha IImu.

Haosana, Cincin. 2012. Pengaruh Return on Asset dan Tobin's Q Terhadap Volume Perdagangan Saham pada Perusahaan Retail yang Terdaftar di Bursa Efek Indonesia. Skripsi S1, Fakultas Ekonomi. Universitas Hasanuddin. Makassar 
Harahap, S. 2010, Analisis Kritis Atas Laporan Keuangan, Jakarta: Penerbit Raja Grafindo Persada.

Harahap, Sofyan S. 2005. Teori Akuntansi. Edisi 8. Jakarta: PT RajaGrafindo Persada.

Hendra, Adhitya. Wicaksono. 2013, Pengaruh Current ratio, debt to asset ratio,Total asset turnover, return on equity, suku bunga, Kurs valuta asing, inflasi dan kas deviden terhadap harga saham perusahaan makanan dan minuman yang terdaftar di BEI periode 2009-2011. Skripsi

Husnan, S dan E. Pudjiastuti. 2006. Dasar-Dasar Manajemen Keuangan, Yogyakarta: Edisi Kelima. Cetakan Pertama. UPP STIM YKPN.

Kasmir. 2013, Analisis Laporan Keuangan, Jakarta: Penerbit Bumi Aksa.

Kasmir. 2012. Analisis Laporan Keuangan. PT.Raja Grafindo Persada, Jakarta.

Kasmir. 2015. Analisis Laporan Keuangan, Jakarta: Edisi Pertama. Cetakan Kedelapan. Rajawali Pers.

Kieso, Donald E., Jerry J. Weygandt, dan Terry D. Warfield. 2008. Akuntansi Intermediate. Edisi 12. Jakarta: Erlangga.

Kuncoro, M. 2013. Metode Riset untuk Bisnis \& Ekonomi, Jakarta: Edisi Keempat. Erlangga.

Martono, dan Agus Harjito. 2005. Manajemen Keuangan. Yogyakarta: Ekonisia.

Oktrima, Bulan. 2017. Pengaruh Profitabilitas, Likuiditas, Dan Struktur Modal Terhadap Nilai Perusahaan. Open Journal. Universitas Pamulang

Pasaribu, F.B. 2008, The Influence of corporate fundamental To Its Stock Price Case Study of Indonesia Stock Excange, Jurnal Of Economic and Busuness, Vol 2, no.2, ISSN:1978-3116, July 2008. Econarch Institute.

PSAK No. 1 Tahun 2015

Sri Zuliarni. 2012. Pengaruh Kinerja Keuangan Terhadap Harga Saham Pada Perusahaan Mining and Mining Service di Bursa Efek Indonesia (BEI). Jurnal Aplikasi Bisnis Vol. 3 No. 1, Oktober 2012.

Sugiyono. 2014. Metode Penelitian Kuantitatif, Kualitatif, dan Kombinasi (Mixed Methods). Bandung: Alfabeta. BPFE.

Sugiyono. 2014. Metode Penelitian Manajemen, Bandung: Alfabeta

Suliyanto. 2011. Ekonometrika Terapan Teori dan Aplikasi dengan SPSS, Yogyakarta: ANDI.

Winarno, Wing Wahyu. 2015. Analisis Ekonometrika dan Statistik dengan Eviews. Yogyakarta. UPP STIM YKPN

http://web.idx.id 